\title{
PAPILIO AGENOR.
}

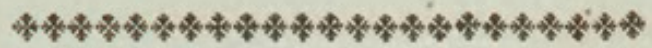

\section{Character GeNericus.}

Antenna apicem versus crassiores, sæpius clavato-capitatæ.

Alce (sedentis) erectæ sursumque conniventes, (volatu diurno.)

Lin. Syst. Nat. p. 744.

CHARACTER SPECIFICUS, छ̈C.

PAPILIO alis dentatis nigris basi sanguineis, primoribus striatis, posticis disco albo maculis nigris.

Lin. Syst. Nat. p. 747 .

Clerk. ic. ins. rar. t. 15.

Cram. pap. 3. t. 32 . f. A. B.

Jablonsky pap. 1. t. 8. f. 3.

In variis Asiæ regionibus generatur Papilio Agenor, magnitudine vera in tabula depictus. 



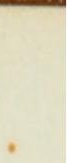




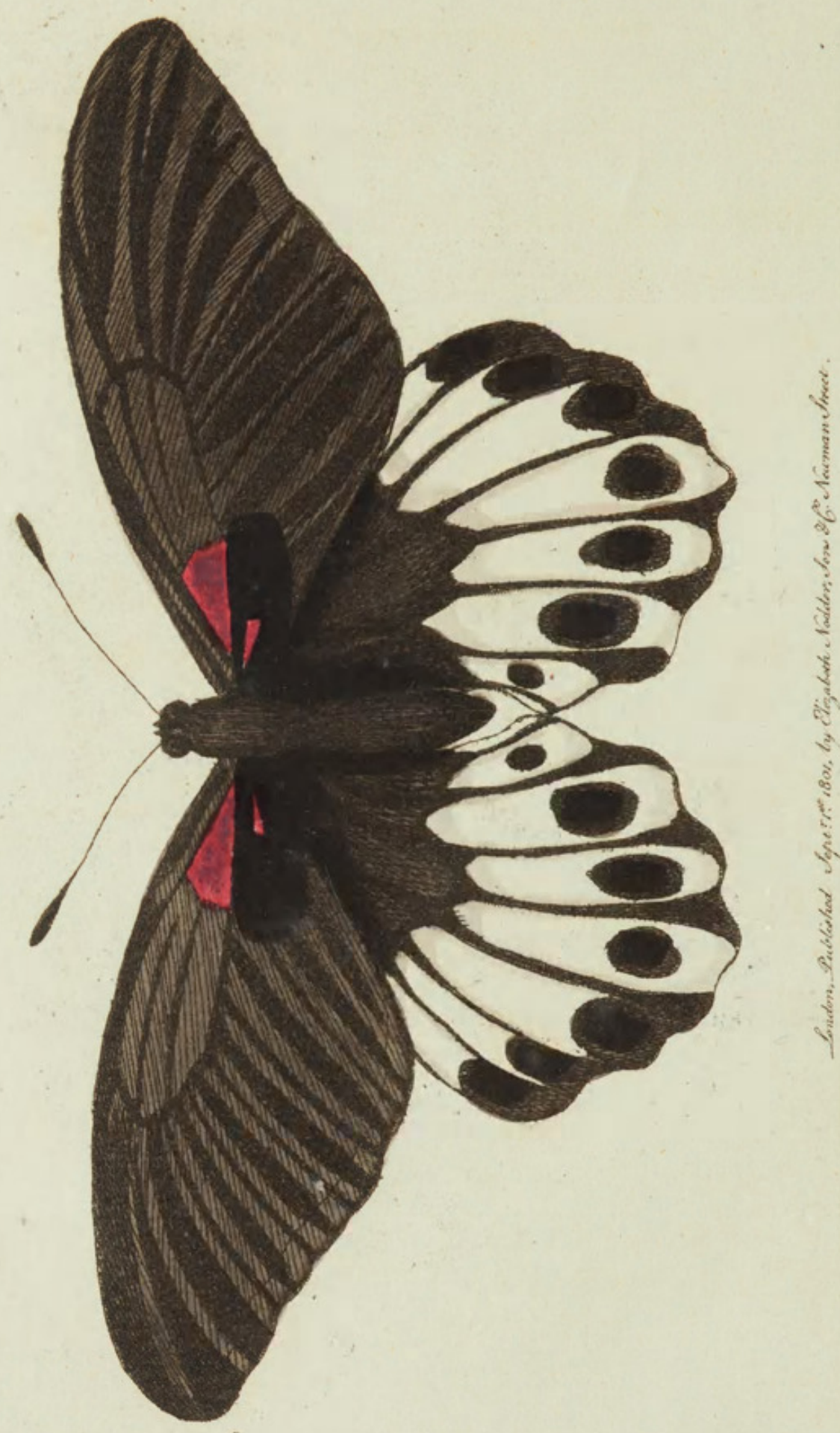




\section{AGENOR.}

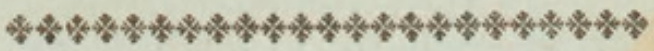

\section{GeNERIC ChaRACTER.}

Antenna commonly thickening towards the end into a clavated tip.

Wings (when at rest) meeting upwards. (Flight diurnal.)

\section{SPECIFIC CHARACTER.}

Black Butterfly with dentated wings red at the base; the lower pair white on the disk, with black spots.

This elegant insect is found in several of the Asiatic regions, and is represented on the plate in its natural size. 


\section{$2 \mathrm{BHL}$ Biodiversity Heritage Library}

Shaw, George. 1802. "Agenor, Papilio agenor [PI. 500]." The Naturalist's Miscellany 13(CLIV), https://doi.org/10.5962/p.310946.

View This Item Online: https://www.biodiversitylibrary.org/item/281546

DOI: https://doi.org/10.5962/p.310946

Permalink: https://www.biodiversitylibrary.org/partpdf/310946

\section{Holding Institution}

Museums Victoria

\section{Sponsored by}

Atlas of Living Australia

\section{Copyright \& Reuse}

Copyright Status: Public domain. The BHL considers that this work is no longer under copyright protection.

This document was created from content at the Biodiversity Heritage Library, the world's largest open access digital library for biodiversity literature and archives. Visit BHL at https://www.biodiversitylibrary.org. 